Article

\title{
New Cytotoxic Cyclic Peptide from the Marine Sponge-Associated Nocardiopsis sp. UR67
}

\author{
Alyaa Hatem Ibrahim ${ }^{1}$, Eman Zekry Attia ${ }^{2}$, Dina Hajjar ${ }^{3}$, Mohamed A. Anany ${ }^{4,5}$, \\ Samar Yehia Desoukey ${ }^{2}$, Mostafa Ahmed Fouad ${ }^{2}$, Mohamed Salah Kamel ${ }^{6}$, Harald Wajant 4 (iD, \\ Tobias A. M. Gulder ${ }^{7, *}$ and Usama Ramadan Abdelmohsen ${ }^{2, *}$ (i) \\ 1 Department of Pharmacognosy, Faculty of Pharmacy, Sohag University, 82524 Sohag, Egypt; \\ dralyaahatem@gmail.com \\ 2 Department of Pharmacognosy, Faculty of Pharmacy, Minia University, 61519 Minia, Egypt; \\ eman_zekry@mu.edu.eg (E.Z.A.); drsamaryehia@gmail.com (S.Y.D.); m_fouad2000@yahoo.com (M.A.F.) \\ 3 Department of Biochemistry, Faculty of Science, Center for Science and Medical Research, \\ University of Jeddah, 80203 Jeddah, Saudi Arabia; dhajjar@uj.edu.sa \\ 4 Division of Molecular Internal Medicine, Department of Internal Medicine II, University Hospital Würzburg, \\ Röntenring 11, 97070 Würzburg, Germany; Mohamed_M@klinik.uni-wuerzburg.de (M.A.A.); \\ harald.wajant@uni-wuerzburg.de (H.W.) \\ 5 Division of Genetic Engineering and Biotechnology, Department of Microbial Biotechnology, \\ National Research Centre, El Buhouth St., Dokki, 12622 Giza, Egypt \\ 6 Department of Pharmacognosy, Faculty of Pharmacy, Deraya University, Universities Zone, \\ 61111 New Minia City, Egypt; mskamel@yahoo.com \\ 7 Biosystems Chemistry, Department of Chemistry and Center for Integrated Protein Science Munich (CIPSM), \\ Technical University of Munich, Lichtenbergstraße 4, 85748 Garching, Germany \\ * Correspondence: tobias.gulder@ch.tum.de (T.A.M.G.); usama.ramadan@mu.edu.eg (U.R.A.); \\ Tel.: +49-89-289-13833 (T.A.M.G.); +20-86234-9075 (U.R.A.); Fax: +20-86237-6678 (U.R.A.)
}

Received: 30 July 2018; Accepted: 17 August 2018; Published: 21 August 2018

\begin{abstract}
A new cyclic hexapeptide, nocardiotide A (1), together with three known compounds-tryptophan (2), kynurenic acid (3), and 4-amino-3-methoxy benzoic acid (4)-were isolated and identified from the broth culture of Nocardiopsis sp. UR67 strain associated with the marine sponge Callyspongia sp. from the Red Sea. The structure elucidation of the isolated compounds were determined based on detailed spectroscopic data including ${ }^{1} \mathrm{D}$ and ${ }^{2} \mathrm{D}$ nuclear magnetic resonance (NMR) experimental analyses in combination with high resolution electrospray ionization mass spectrometry (HR-ESI-MS), while the absolute stereochemistry of all amino acids components of nocardiotide A (1) was deduced using Marfey's method. Additionally, ten known metabolites were dereplicated using HR-ESI-MS analysis. Nocardiotide A (1) displayed significant cytotoxic effects towards the murine CT26 colon carcinoma, human HeLa cervix carcinoma, and human MM.1S multiple myeloma cell lines. The results obtained revealed sponge-associated Nocardiopsis as a substantial source of lead natural products with pronounced pharmacological activities.
\end{abstract}

Keywords: Nocardiopsis; cyclic hexapeptide; cytotoxicity; marine actinomycetes; sponges

\section{Introduction}

Actinomycetes are a diverse group of aerobic Gram-positive microorganisms withhigh guanine-cytosine DNA content [1]. They belong to the phylum Actinobacteria, which is one of the largest bacterial phyla, distributed in both terrestrial and marine ecosystems [2,3]. About $70 \%$ of all naturally derived drugs in clinical use originate from Actinobacteria as they contain biologically active secondary metabolites accounting for their clinical use, mainly as antibacterial, antifungal, 
antiviral, and cytotoxic drugs [4-6]. The genus Nocardiopsis was first described by Mayer in 1976 [7] as belonging to the family Nocardiopsaceae and as morphologically similar to members of the genera Actinomadura and Nocardia [7,8]. By reviewing the literature on the genus Nocardiopsis $[9,10]$, it has been clearly demonstrated that it is a prolific producer of a wide variety of bioactive compounds, mainly cyclic peptides [11,12], polyketides [13,14], macrolides [15], alkaloids [16], diketopiperazines [17,18], $\alpha$ and $\gamma$-pyrones [19,20], naphthoquinones [21], phenazines [22], and phenoxazine derivatives [23], which contributes to a broad spectrum of biological activities, mainly as cytotoxic [21], anticancer [22], antitumor [24], antibacterial [11], antifungal [25], immunemodulatory [15], and protein kinase inhibitory [26].

Cancer still remains one of the most serious challenges to human health. Despite intense efforts to develop treatments, effective-particularly highly selective-agents are still not available for many cancer types. Therefore, it is necessary to continue the discovery of new classes of molecules with cytotoxic activity. One strategy to treat cancer is to find compounds with new scaffolds that have increased chances of possessing novel binding modes or even addressing novel targets. Consequently, this current investigation is a continuation of our efforts to seek new, effective cytotoxic agents from actinomycetes-associated with marine sponges, specifically, the Nocardiopsis sp. UR67 strain—and to evaluate their cytotoxic biological activities.

\section{Results and Discussion}

Nocardiopsis sp. UR67 was cultivated from the sponge Callyspongia sp. (family Callyspongiidae) that was collected from the Red Sea (Ras Mohamed, Sinai, Egypt; (GPS: $27^{\circ} 47.655^{\prime}$ N; $34^{\circ} 12.904^{\prime}$ W) in August 2008. ISP2 liquid broth with calcium alginate beads [27] of Nocardiopsis sp. UR67 was extracted with ethyl acetate, and the obtained organic extract was fractionated on Sephadex LH20. This was followed by purification using semi-preparative reversed phase high performance liquid chromatography (HPLC) to yield a new cyclic hexapeptide nocardiotide A (1), along with three known compounds-tryptophan (2), kynurenic acid (3), which was isolated for the first time from microbial origins, and 4-amino-3-methoxy benzoic acid (4) (Figure 1).
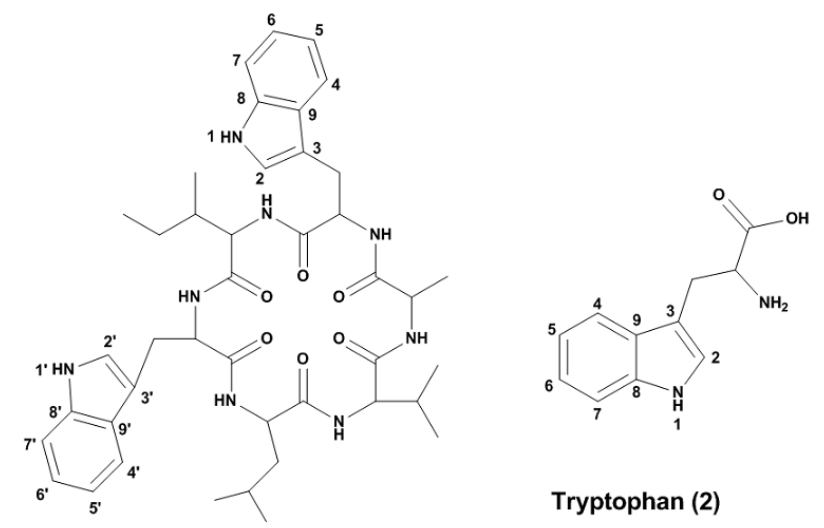

Nocardiotide A (1)
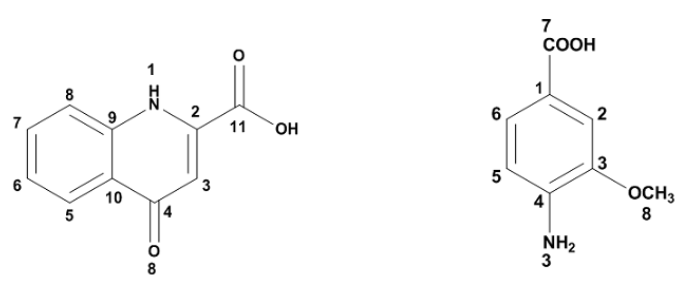

Kynurenic acid (3)

4-Amino-3-methoxy benzoic acid (4)

Figure 1. Structures of the isolated compounds. 


\subsection{Metabolomic Analysis}

HPLC high resolution electrospray ionization mass spectrometry (HPLC-HR-ESIMS) analysis for dereplication purpose was used for identification of the metabolites from the ethyl acetate extract obtained from the culture broth of Nocardiopsis sp. UR67. The dereplication study of the metabolites (Figure 2, Table 1) against the Dictionary of Natural Products (DNP) database, AntiMarin, and METLIN databases led to the characterization of the following natural products: cytotoxic peptide lucentamycin C [28], immunosuppressant kanglemycin M [29], 8-hydroxy-3methoxy-1-methyl-anthraquinone-2-carboxylic acid [30], antimicrobial, antitumor and insecticidal piericidin-C3 [31], sotetracenone-type antitumor atramycin B [32], piericidin group antibiotic IT-143-B [33], antibiotic lankacyclinol-A [34], antifungal polyketide ansatrienin A [35], actinoramide B [36] and, finally, a potent apoptosis inducer polyoxypeptin A [37].
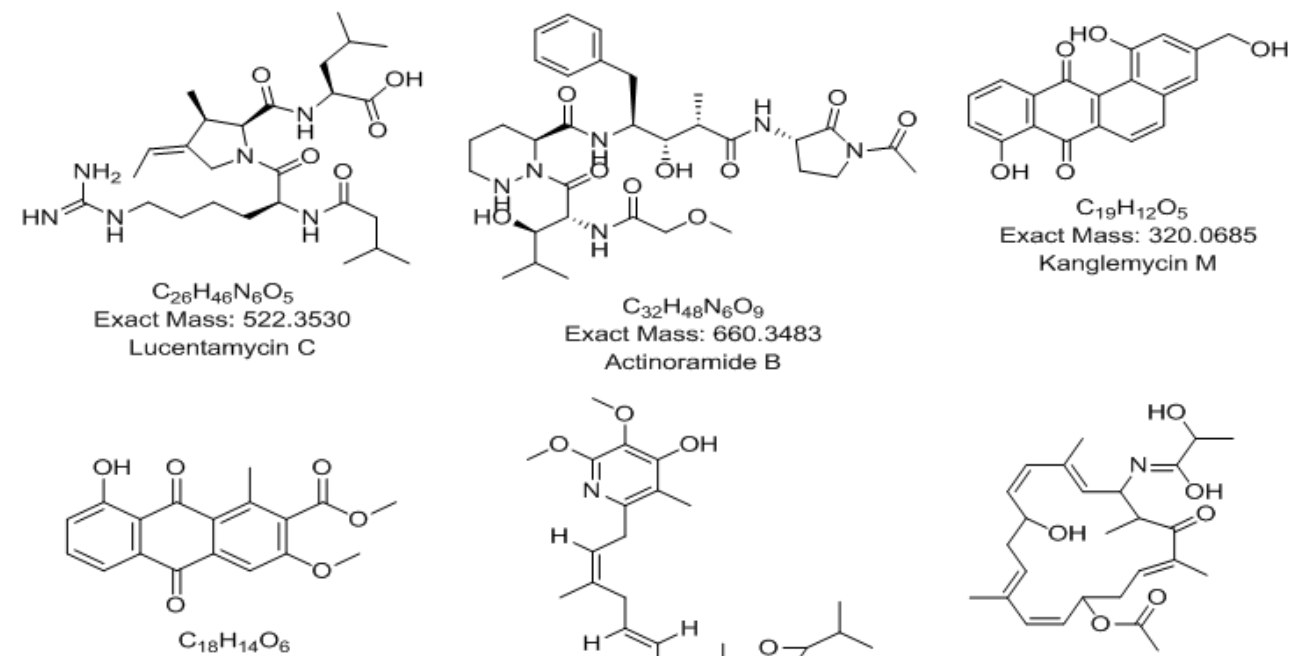

Exact Mass: 326.0790

8-Hydroxy-3-methoxy-1 methylanthraquinone-2-carboxylic acid methyl ester<smiles>CC1CC(=O)c2c(ccc3c2C(=O)c2cccc(OC4O[C@H](C)[C@@H](O)[C@H](O)[C@H]4O)c2C3=O)C1</smiles>
$\mathrm{C}_{32} \mathrm{H}_{48} \mathrm{~N}_{6} \mathrm{O}_{9}$
Exact Mass: 660.3483 Actinoramide B
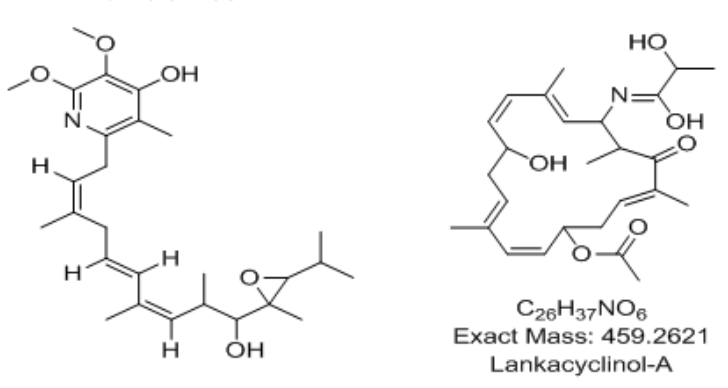

$\mathrm{C}_{27} \mathrm{H}_{41} \mathrm{NO}_{5}$

Exact Mass: 459.2985 Piericidin-C3

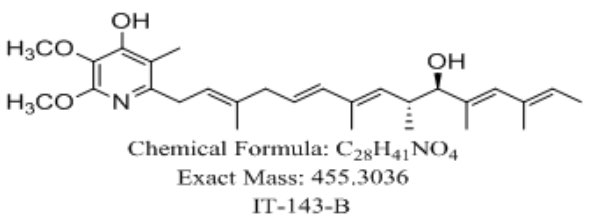

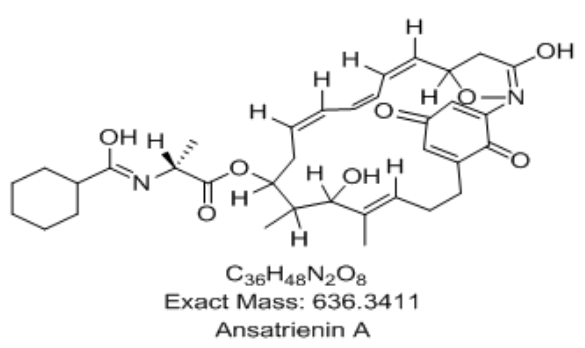

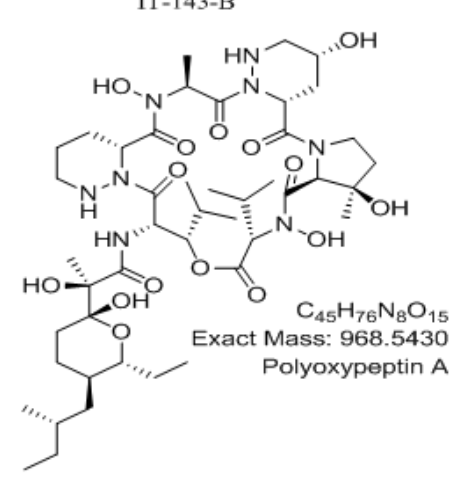

Figure 2. Dereplicated metabolites from metabolomic analysis of Nocardiopsis sp. UR67. 
Table 1. The dereplication results of the ethyl acetate fraction.

\begin{tabular}{cccccc}
\hline Polarity & $m / z$ & Rt (min) & Formula & Name & Source \\
\hline$[\mathrm{M}+\mathrm{H}]^{+}$ & 327.0866 & 2.91 & $\mathrm{C}_{18} \mathrm{H}_{14} \mathrm{O}_{6}$ & $\begin{array}{c}\text { 8-Hydroxy-3-methoxy-1- } \\
\text { methylanthraquinone-2- } \\
\text { carboxylic acid }\end{array}$ & Streptomyces sp. \\
\hline$[\mathrm{M}-\mathrm{H}]^{-}$ & 967.5399 & 3.53 & $\mathrm{C}_{45} \mathrm{H}_{76} \mathrm{~N}_{8} \mathrm{O}_{15}$ & Polyoxypeptin A & Streptomyces sp. MK498-98 F14 \\
\hline$[\mathrm{M}-\mathrm{H}]^{-}$ & 635.3316 & 3.81 & $\mathrm{C}_{36} \mathrm{H}_{48} \mathrm{~N}_{2} \mathrm{O}_{8}$ & Ansatrienin A & Streptomyces collinus \\
\hline$[\mathrm{M}+\mathrm{H}]^{+}$ & 321.0760 & 4.6 & $\mathrm{C}_{19} \mathrm{H}_{12} \mathrm{O}_{5}$ & Kanglemycin $\mathrm{M}$ & $\begin{array}{c}\text { Nocardiamediterranei var. } \\
\text { kanglensis 1747-64 }\end{array}$ \\
\hline$[\mathrm{M}+\mathrm{H}]^{+}$ & 661.3568 & 6.41 & $\mathrm{C}_{32} \mathrm{H}_{48} \mathrm{~N}_{6} \mathrm{O}_{9}$ & Actinoramide B & $\begin{array}{c}\text { Streptomyces ballenaensis and } \\
\text { Streptomyces bangulaensis }\end{array}$ \\
\hline$[\mathrm{M}+\mathrm{H}]^{+}$ & 460.2697 & 6.95 & $\mathrm{C}_{26} \mathrm{H}_{37} \mathrm{NO}_{6}$ & Lankacyclinol-A & Streptomyces rochei var. volubilis \\
\hline$[\mathrm{M}-\mathrm{H}]^{-}$ & 451.1392 & 7.24 & $\mathrm{C}_{25} \mathrm{H}_{4} \mathrm{O}_{8}$ & Atramycin B & Streptomyces atratus \\
\hline$[\mathrm{M}-\mathrm{H}]^{-}$ & 458.2906 & 7.56 & $\mathrm{C}_{27} \mathrm{H}_{41} \mathrm{NO}_{5}$ & Piericidin-C3 & Streptomyces pactum \\
\hline$[\mathrm{M}+\mathrm{H}]^{+}$ & 456.3108 & 7.98 & $\mathrm{C}_{28} \mathrm{H}_{41} \mathrm{NO}_{4}$ & IT-143-B & Streptomyces species \\
\hline$[\mathrm{M}+\mathrm{H}]^{+}$ & 523.3601 & 11.23 & $\mathrm{C}_{26} \mathrm{H}_{46} \mathrm{~N}_{6} \mathrm{O}_{5}$ & Lucentamycin C & Nocardiopsis lucentensis \\
\hline
\end{tabular}

\subsection{Structure Elucidation}

Nocardiotide A (1) was obtained as a pale yellow powder with a molecular formula of $\mathrm{C}_{42} \mathrm{H}_{56} \mathrm{~N}_{8} \mathrm{O}_{6}$ determined by HR-ESI-MS analysis $\left(m / z 791.931[\mathrm{M}+\mathrm{Na}]^{+}\right.$, calcd. for $\left.\mathrm{C}_{42} \mathrm{H}_{56} \mathrm{~N}_{8} \mathrm{O}_{6} \mathrm{Na}\right)$, indicating 19 degrees of unsaturation. The peptidic nature of nocardiotide A (1) was recognized from the ${ }^{1} \mathrm{H}$ and ${ }^{13} \mathrm{C}$ nuclear magnetic resonance (NMR) spectral data (Table 2). The ${ }^{1} \mathrm{H}-\mathrm{NMR}$ spectrum (Figures S1-S3) revealed the presence of six $\alpha$-amino acid hydrogen resonances $\left(\delta_{\mathrm{H}} 3.35-4.37\right)$. Additionally, the ${ }^{13} \mathrm{C}$ NMR spectrum (Figure S4) contained six amide carbonyl signals resonating between $\delta_{C} 171$ and $179 \mathrm{ppm}$ and six $\alpha$-amino acid carbon signals between $\delta_{\mathrm{C}} 41$ and $60 \mathrm{ppm}$, thus corroborating the presence of six amino acid moieties [38,39]. The ${ }^{1} \mathrm{H}-\mathrm{NMR}$ and COSY spectra (Figures S1 and S7) showed two distinct aromatic spin systems $\left(\delta_{\mathrm{H}} 6.85-7.55\right)$, and the ${ }^{13} \mathrm{C}-\mathrm{NMR}$ and ${ }^{13} \mathrm{C}$-DEPT-135 spectrum (Figures $\mathrm{S} 4$ and S5) displayed ten methines and six quaternary carbons consistent with two tryptophan moieties. One tryptophan $\left(\operatorname{Trp}_{1}\right)$ was assigned at $\delta_{\mathrm{H}} 4.37$ $(\mathrm{dd}, J=3.8,9.9 \mathrm{~Hz}, \mathrm{H1}-\alpha), 3.30(\mathrm{dd}, J=14.7,3.8 \mathrm{~Hz}, \mathrm{H} 1-\beta), 3.05\left(\mathrm{dd}, J=14.7,9.98 \mathrm{~Hz}, \mathrm{H} 1-\beta^{\prime}\right)$, 7.03 (s, H1-2), 7.55 (dt, J = 7.84, 0.9 Hz, H1-4), 6.88 (td, overlapped, H1-5), 6.94 (td, overlapped, H1-6), $7.18(\mathrm{dt}, J=8.11,0.9 \mathrm{~Hz}, \mathrm{H1}-7)$, and their corresponding carbons signals were assigned at $\delta_{C} 179.06(\mathrm{CO} 1)$, 56.90 (C1- $\alpha), 29.19$ (C1- $\beta$ ), 124.65 (C1-2), 112.29 (C1-3), 119.55 (C1-4), 119.44 (C1-5), 122.05 (C1-6), $112.04(\mathrm{C} 1-7), 137.98(\mathrm{C} 1-8), 128.92(\mathrm{C} 1-9)$. The other tryptophan residue $\left(\operatorname{Trp}_{2}\right)$ was assigned at $\delta_{\mathrm{H}}$ $3.35(\mathrm{t}, J=8.04 \mathrm{~Hz}, \mathrm{H} 2-\alpha), 2.82(\mathrm{td}, J=8.64,0.9 \mathrm{~Hz}, \mathrm{H} 2-\beta), 6.96\left(\mathrm{~s}, \mathrm{H} 2-2^{\prime}\right), 7.45(\mathrm{dt}, J=7.92,0.9 \mathrm{~Hz}$, $\left.\mathrm{H} 2-4^{\prime}\right), 6.90\left(\mathrm{td}\right.$, overlapped, H2-5'), $6.98(\mathrm{td}$, overlapped, H2-6' $), 7.22\left(\mathrm{dt}, J=8.17,0.9 \mathrm{~Hz}, \mathrm{H} 2-7^{\prime}\right)$, while their corresponding carbons signals were detected at $\delta_{C} 173.24(\mathrm{CO} 2), 41.56(\mathrm{C} 2-\alpha), 26.21(\mathrm{C} 2-\beta)$, $123.33\left(\mathrm{C} 2-2^{\prime}\right), 113.27\left(\mathrm{C} 2-3^{\prime}\right), 119.22$ (C2-4'), $119.44\left(\mathrm{C} 2-5^{\prime}\right), 122.28\left(\mathrm{C} 2-6^{\prime}\right), 112.20\left(\mathrm{C} 2-7^{\prime}\right), 138.17\left(\mathrm{C} 2-8^{\prime}\right)$, $128.80\left(\mathrm{C} 2-9^{\prime}\right)$. These assignments were further confirmed by heteronuclear single quantum coherence (HSQC) and heteronuclear multiple bond correlation (HMBC) correlations (Figure 3) [40]. In addition to these two tryptophan moieties, the ${ }^{13} \mathrm{C}-\mathrm{NMR},{ }^{13} \mathrm{C}$-DEPT-135, and HSQC spectra (Figures S4-S6), displayed seven methyl, two methylene, and seven methine carbons. A spin system characteristic for isoleucine was observed at $\delta_{\mathrm{H}} 4.20(\mathrm{~d}, J=3.9 \mathrm{~Hz}, \mathrm{H}-\alpha), 2.03(\mathrm{~m}, \mathrm{H}-\beta), 0.84(\mathrm{~d}, J=7.0 \mathrm{~Hz}, \mathrm{H}-\gamma)$, $1.28\left(\mathrm{~m}, \mathrm{H}-\gamma^{\prime}\right)$, and $0.85(\mathrm{~d}, J=7.4 \mathrm{~Hz}, \mathrm{H}-\delta)$, while their corresponding carbon signals were observed at $\delta_{C} 58.94(C-\alpha), 36.93(C-\beta), 12.14(C-\gamma), 27.49\left(C-\gamma^{\prime}\right)$, and $14.65(C-\delta)$, respectively. The previous assignments were corroborated using HSQC experiment (Figure S6). In addition, HMBC correlation (Figure S10) from $\alpha$-proton of isoleucine $\left(\delta_{\mathrm{H}} 4.20, \mathrm{~d}, J=3.9 \mathrm{~Hz}\right)$ to its own amide-type carbonyl at $\delta_{\mathrm{C}} 173.42$ was detected. Furthermore, an alanine spin system was displayed at $\delta_{\mathrm{H}} 4.31(\mathrm{q}, J=7.2 \mathrm{~Hz}$, $\mathrm{H}-\alpha)$, and $1.17(\mathrm{~d}, J=7.2 \mathrm{~Hz}, \mathrm{H}-\beta)$, and their corresponding carbons were observed at $\delta_{\mathrm{C}} 49.77(\mathrm{C}-\alpha)$ and $18.05(C-\beta)$, respectively. The $\alpha$ and $\beta$ protons of alaninemoiety $\left(\delta_{H} 4.31\right.$ and 1.17 , respectively) 
showed a strong $\mathrm{HMBC}$ correlations with their amide-type carbonyl at $\delta_{\mathrm{C}} 173.93$. Additionally, a spin system for a leucine residue was observed at $\delta_{\mathrm{H}} 3.81(\mathrm{t}, J=7.3 \mathrm{~Hz}, \mathrm{H}-\alpha), 1.59(\mathrm{~m}, \mathrm{H}-\beta), 1.62(\mathrm{~m}, \mathrm{H}-\gamma)$, $0.92(\mathrm{~d}, J=6.2 \mathrm{~Hz}, \mathrm{H}-\delta)$, and $0.93\left(\mathrm{~d}, J=6.2 \mathrm{~Hz}, \mathrm{H}-\delta^{\prime}\right)$, and their corresponding carbons were assigned at $\delta_{C} 52.97(C-\alpha), 41.95(C-\beta), 25.60(C-\gamma), 22.56(C-\delta)$, and $22.85\left(C-\delta^{\prime}\right)$, respectively, using HSQC experiment correlation. Moreover, the $\alpha$ and $\beta$ protons of leucine residue exhibited HMBC correlations with their amide-type carbonyl at $\delta_{C} 171.56$. Finally, a valine moiety was detected from the spin system at $\delta_{\mathrm{H}} 4.22(\mathrm{~d}, J=7.7 \mathrm{~Hz}, \mathrm{H}-\alpha), 1.97(\mathrm{~m}, \mathrm{H}-\beta), 0.88(\mathrm{~d}, J=3.1 \mathrm{~Hz}, \mathrm{H}-\gamma)$, and $0.89(\mathrm{~d}, J=3.1 \mathrm{~Hz}$, $\left.\mathrm{H}-\gamma^{\prime}\right)$, and their corresponding carbons were displayed at $\delta_{\mathrm{C}} 60.76(\mathrm{C}-\alpha), 31.75(\mathrm{C}-\beta), 19.79(\mathrm{C}-\gamma)$, and $18.95\left(\mathrm{C}-\gamma^{\prime}\right)$, respectively. The amide-type carbonyl at $\delta_{C} 175.33$ was attributed to the valine residue, which could be confirmed from the strong HMBC correlations observed amongst $\alpha$ and $\beta$ protons of valine moiety [40]. Detailed analysis of the ${ }^{1} \mathrm{D}\left({ }^{1} \mathrm{H},{ }^{13} \mathrm{C}\right.$ and DEPT-135) and ${ }^{2} \mathrm{D}$ (HSQC, HMBC and NOE) NMR spectroscopic data (Table 2) revealed that nocardiotide A (1) was a hexapeptide containing Ile, Leu, Val, Ala, and two Trp residues. The amino acid sequence was elucidated to be Ile-Trp ${ }_{1}$-Ala-Val-Leu-Trp 2 on the basis of the following HMBC correlations (Figures S10 and S11): $\alpha-\operatorname{Trp}_{1}\left(\delta_{\mathrm{H}} 4.37\right) /$ Ala-CO $\left(\delta_{\mathrm{C}} 173.9\right), \alpha$-Val $\left(\delta_{\mathrm{H}} 4.22\right) /$ Leu-CO $\left(\delta_{\mathrm{C}} 171.5\right)$ and the following NOE correlations (Figures S8 and S9): $\operatorname{Trp}_{1} \mathrm{H}-2\left(\delta_{\mathrm{H}} 7.02\right) / \alpha$-Ile $\left(\delta_{\mathrm{H}} 4.20\right), \alpha$-Ala $\left(\delta_{\mathrm{H}} 4.31\right) / \alpha$-Val $\left(\delta_{\mathrm{H}} 4.22\right)$, $\alpha$-Val $\left(\delta_{\mathrm{H}} 4.22\right) / \alpha$-Leu $\left(\delta_{\mathrm{H}} 3.81\right), \alpha$-Ile $\left(\delta_{\mathrm{H}} 4.20\right) / \beta, \beta^{\prime} \operatorname{Trp}_{2}\left(\delta_{\mathrm{H}} 2.82\right)$ and $\operatorname{Trp}_{2} \mathrm{H}-4^{\prime}\left(\delta_{\mathrm{H}} 7.45\right) / \alpha$-Leu $\left(\delta_{\mathrm{H}} 3.81\right)$ (Table 2, Figure 3) [38,41].

These six amino acids accounted for18 degrees of unsaturation, indicating that nocardiotide A (1) was a monocyclic hexapeptide. The absolute configurations of the amino acid units in nocardiotide A (1) were determined by acid hydrolysis, followed by chiral derivatization with Marfey's reagent (1-fluoro-2,4-dinitrophenyl-5-lalanine amide, FDAA). HPLC analysis of the Marfey's derivatives in comparison to their respective D-and L-authentic reference amino acids revealed the absolute configuration of all amino acids of the new cyclic hexapeptideto beL.
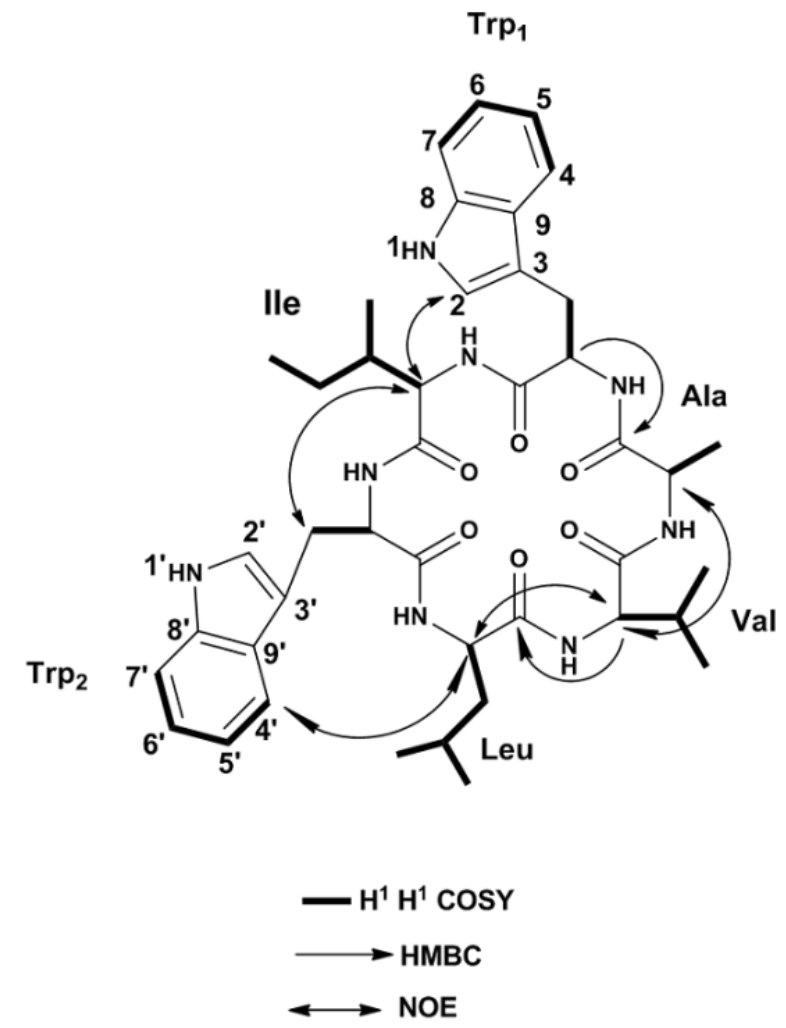

Figure 3. Significant COSY, heteronuclear multiple bond correlation (HMBC), and NOE correlations of nocardiotide A (1). 
Table 2. NMR-spectroscopic data of nocardiotide A (1) in MeOD- $\mathrm{d}_{4}\left({ }^{1} \mathrm{H}: 600 \mathrm{MHz} ;{ }^{13} \mathrm{C}: 150 \mathrm{MHz}, \delta\right.$ in ppm, $J$ in $\mathrm{Hz}$ ).

\begin{tabular}{|c|c|c|c|c|c|}
\hline Aminoacids & $\delta_{C}$ & $\delta_{\mathrm{H}}$, mult $(\mathrm{J}$ in $\mathrm{Hz})$ & COSY & НМВС & NOESY \\
\hline \multicolumn{6}{|l|}{ Ile } \\
\hline $\mathrm{CO}$ & 173.42 & & & & \\
\hline$\alpha$ & 58.94 & $4.20, \mathrm{~d}(4.6)$ & $\beta$ & $\mathrm{CO}, \beta, \gamma^{\prime}, \delta$ & $\beta-\operatorname{Trp}_{2}$ \\
\hline$\beta$ & 36.93 & $2.03, \mathrm{~m}$ & $\alpha, \gamma, \gamma^{\prime}$ & $\gamma^{\prime}, \delta$ & \\
\hline$\gamma$ & 12.14 & $0.84, \mathrm{~d}(7.0)$ & $\gamma^{\prime}, \beta$ & & \\
\hline$\gamma^{\prime}$ & 27.49 & $1.28, \mathrm{~m}$ & $\beta, \gamma, \delta$ & $\alpha, \beta, \gamma, \delta$ & \\
\hline$\delta$ & 14.65 & $0.85, \mathrm{~d}(7.4)$ & $\gamma^{\prime}$ & $\alpha, \beta, \gamma^{\prime}$ & \\
\hline \multicolumn{6}{|l|}{$\operatorname{Trp}_{1}$} \\
\hline $\mathrm{CO}$ & 179.06 & & & & \\
\hline$\alpha$ & 56.90 & $4.37, \mathrm{dd}(3.8,9.9)$ & $\beta, \beta^{\prime}$ & $\mathrm{CO}, \beta / \beta^{\prime}, \mathrm{C}-3, \mathrm{Ala}-\mathrm{CO}$ & \\
\hline$\beta$ & 29.19 & $3.05, \mathrm{dd}(14.7,9.9)$ & $\alpha$ & $\mathrm{CO}, \alpha, \mathrm{C}-2, \mathrm{C}-3, \mathrm{C}-8, \mathrm{C}-9$ & \\
\hline$\beta^{\prime}$ & 29.19 & 3.30, dd $(14.7,3.8)$ & $\alpha$ & & \\
\hline 2 & 124.65 & $7.03(\mathrm{~s})$ & & $\beta / \beta^{\prime}, C-3, C-8, C-9$ & $\alpha$-Ileu \\
\hline 3 & 112.29 & & & & \\
\hline 4 & 119.55 & $7.55, \mathrm{dt}(7.84,0.9)$ & H-5, H-6, H-7 & $C-3, C-6, C-8, C-9$ & \\
\hline 5 & 119.44 & $6.88 \mathrm{~m}$ & H-4, H-6, H-7 & C-7, C-9 & \\
\hline 6 & 122.05 & $6.94(\mathrm{~m})$ & $\mathrm{H}-4, \mathrm{H}-5, \mathrm{H}-7$ & C $-4, C-9$ & \\
\hline 7 & 112.04 & $7.18, \mathrm{dt}(8.11,0.9)$ & H-4, H-5, H-6 & $C-5, C-9$ & \\
\hline 8 & 137.98 & & & & \\
\hline 9 & 128.92 & & & & \\
\hline \multicolumn{6}{|l|}{ Ala } \\
\hline $\mathrm{CO}$ & 173.93 & & & & \\
\hline$\alpha$ & 49.77 & $4.31, q,(7.2)$ & $\beta$ & $\mathrm{CO}, \beta$ & $\alpha$-Val \\
\hline$\beta$ & 18.05 & $1.17, \mathrm{~d},(7.2)$ & $\alpha$ & $\mathrm{CO}, \alpha$ & \\
\hline \multicolumn{6}{|l|}{ Val } \\
\hline $\mathrm{CO}$ & 175.33 & & & & \\
\hline$\alpha$ & 60.76 & $4.22, \mathrm{~d}(7.7)$ & $\beta$ & $\mathrm{CO}, \mathrm{Leu}-\mathrm{CO}, \beta, \gamma^{\prime}$ & $\alpha$-Leu \\
\hline$\beta$ & 31.75 & $1.97, \mathrm{~m}$ & $\alpha, \gamma, \gamma^{\prime}$ & $\mathrm{CO}, \alpha, \gamma$ & \\
\hline$\gamma$ & 19.79 & $0.88, \mathrm{~d}(3.1)$ & $\beta$ & $\alpha, \beta, \gamma^{\prime}$ & \\
\hline$\gamma^{\prime}$ & 18.95 & $0.9, \mathrm{~d}(3.1)$ & $\beta$ & $\alpha, \beta, \gamma$ & \\
\hline \multicolumn{6}{|l|}{ Leu } \\
\hline $\mathrm{CO}$ & 171.56 & & & & \\
\hline$\alpha$ & 52.97 & $3.81, \mathrm{t}(7.3)$ & $\beta$ & $\mathrm{CO}, \beta, \gamma$ & \\
\hline$\beta$ & 41.95 & $1.59, \mathrm{~m}$ & $\alpha, \gamma$ & $\mathrm{CO}, \alpha, \gamma, \delta, \delta^{\prime}$ & \\
\hline$\gamma$ & 25.60 & $1.62, \mathrm{~m}$ & $\beta, \delta, \delta^{\prime}$ & $\alpha, \beta, \delta, \delta^{\prime}$ & \\
\hline$\delta$ & 22.56 & $0.92, \mathrm{~d}(6.2)$ & $\gamma$ & $\beta, \gamma, \delta^{\prime}$ & \\
\hline$\delta^{\prime}$ & 22.85 & $0.93, \mathrm{~d}(6.2)$ & $\gamma$ & $\beta, \gamma, \delta$ & \\
\hline \multicolumn{6}{|l|}{$\operatorname{Trp}_{2}$} \\
\hline $\mathrm{CO}$ & 173.24 & & & & \\
\hline$\alpha$ & 41.56 & $3.35, \mathrm{t}(8.04)$ & $\beta / \beta^{\prime}$ & $C O, \beta / \beta^{\prime}, C-3^{\prime}$ & \\
\hline$\beta / \beta^{\prime}$ & 26.21 & $2.82, \mathrm{td}(8.64,0.9)$ & $\alpha$ & $\alpha, C-2^{\prime}, C-3^{\prime}, C-9^{\prime}$ & $\alpha$-Ile \\
\hline $2^{\prime}$ & 123.33 & $6.96, \mathrm{~s}$ & & $\alpha, \beta / \beta^{\prime}$ & \\
\hline $3^{\prime}$ & 113.27 & & & & \\
\hline $4^{\prime}$ & 119.22 & $7.45, \mathrm{dt}(7.92,0.9)$ & $\mathrm{H}-5^{\prime}, \mathrm{H}-6^{\prime}, \mathrm{H}-7^{\prime}$ & $\mathrm{C}-3^{\prime}, \mathrm{C}-6^{\prime}, \mathrm{C}-8^{\prime}, \mathrm{C}-9^{\prime}$ & \\
\hline $5^{\prime}$ & 119.44 & $6.90, \mathrm{~m}$ & $\mathrm{H}-4^{\prime}, \mathrm{H}-6^{\prime}, \mathrm{H}-7^{\prime}$ & $C-7^{\prime}, C-9^{\prime}$ & \\
\hline $6^{\prime}$ & 122.28 & $6.98, \mathrm{~m}$ & $\mathrm{H}-4^{\prime}, \mathrm{H}-5^{\prime}, \mathrm{H}-7^{\prime}$ & $C-4^{\prime}, C-9^{\prime}$ & \\
\hline $7^{\prime}$ & 112.20 & $7.22, \mathrm{dt}(8.17,0.9)$ & $\mathrm{H}-4^{\prime}, \mathrm{H}-{ }^{\prime} 5, \mathrm{H}-6^{\prime}$ & $C-5^{\prime}, C-9^{\prime}$ & \\
\hline $8^{\prime}$ & 138.7 & & & & \\
\hline $9^{\prime}$ & 128.80 & & & & \\
\hline
\end{tabular}

Additionally, three known compounds-tryptophan (2), kynurenic acid (3), and 4-amino-3-methoxy benzoic acid (4) (Figure 1) - were also separated and could be identified by comparing their ${ }^{1} \mathrm{D}$ and ${ }^{2} \mathrm{D}$ NMR spectral analysis (Figures S12-S26) with the published data [42,43]. It is worth mentioning that kynurenic acid (3) was isolated for the first time from microbial origins.

\subsection{Biological Activities of the Isolated Compounds}

The four aforementioned isolated compounds were examined for their cytotoxicity potential towards the murine CT26 colon carcinoma, the human HeLa cervix carcinoma, and the human MM.1S 
multiple myeloma cell lines. Nocartiodite A (1) displayedprominent cytotoxic features with $\mathrm{IC}_{50}$ values of 8,11 , and $12 \mu \mathrm{M} / \mathrm{mL}$ against the human MM. 1S multiple myeloma, human HeLa cervix carcinoma, and murine CT26 colon carcinoma, respectively (Figure 4). Tryptophan (2), kynurenic acid (3), and4-amino-3-methoxy benzoic acid (4) did not demonstrate any considerable cell death properties at the examined concentration.
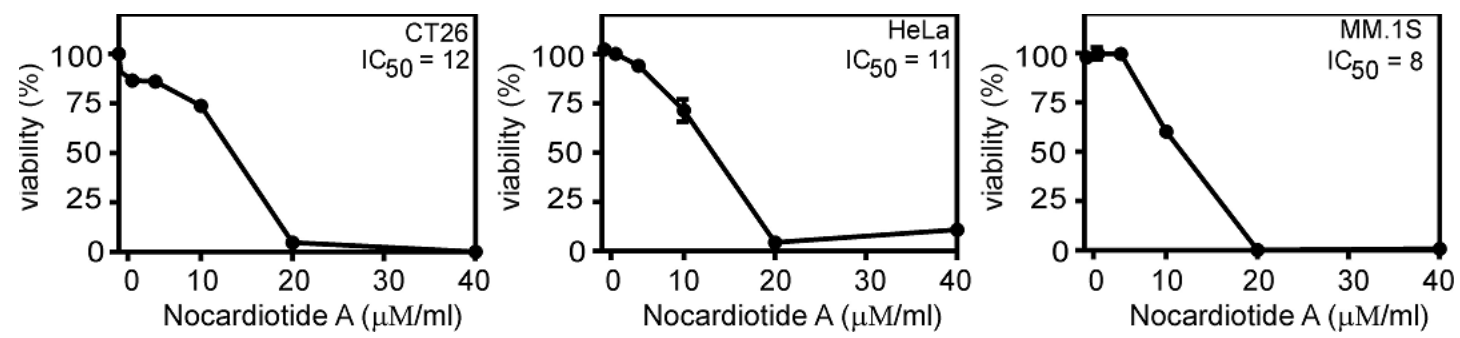

Figure 4. Nocardiotide A induces cell death in CT26, HeLa, and MM.1S cell lines.

\section{Materials and Methods}

\subsection{General Experimental Procedures}

Melting points were measured using Stuart Scientific (SMPI) melting point apparatus and were uncorrected. An ultraviolet lamp (CAMAG, Wilmington, NC, USA) was used for visualization of spots on thin layer chromatograms at 254 and / or $365 \mathrm{~nm} .{ }^{1} \mathrm{H}(600 \mathrm{MHz})$ and ${ }^{13} \mathrm{C}(150 \mathrm{MHz}) \mathrm{NMR}$ spectra were recorded on BrukerAvance III HD 600 instruments (Bruker Biospin, Rheinstetten, Germany) in $\mathrm{CD}_{3} \mathrm{OD}$. The samples were degassed by an ultrasonic water bath (Branson 3800 Ultrasonic Cleaner, Branson, Gayton, UK) for 20 min before measurements. Solvent signals of $\mathrm{CD}_{3} \mathrm{OD}\left(\delta_{\mathrm{H}} 3.3 \mathrm{ppm}\right.$ and $\delta_{\mathrm{C}} 49.0 \mathrm{ppm}$ ) were considered as the internal reference signals for calibration. Chemical shift values $(\delta)$ were recorded in ppm units and coupling constants $(J)$ in Hz. Heteronuclear correlations were measured using HSQC (optimized for $1 J_{H C}=145 \mathrm{~Hz}$ ) and $\mathrm{HMBC}$ (optimized for $\mathrm{n} J_{H C}=8.3 \mathrm{~Hz}$ or $\mathrm{n} J_{H C}$ $=4.0 \mathrm{~Hz}$ ) pulse sequences. Positive and negative HR-ESI-MS spectra were obtained using a Synapt G2 HDMS QTOF-mass spectrometer (Waters, Eschborn, Germany). HPLC separations and purifications were performed on the Knauer system (Knauer, Berlin, Germany). This included Smartline S-1000 quaternary pumps coupled with a Smartline S-2600 UV-VIS multiwavelength detector (Knauer, Berlin, Germany), a Knauer dynamic mixing chamber, and using a C18 column $(5 \mu \mathrm{m}, 10 \mathrm{~mm} \times 250 \mathrm{~mm}$, Knauer, Berlin, Germany) at ambient temperature with a guard column filled with the same stationary phase. On the other hand, the analytical detection was carried out using an analytical Gemini-NX RP-18 column $(5 \mu \mathrm{m}, 4.60 \mathrm{~mm} \times 100 \mathrm{~mm}$; Phenomenex, Aschaffenburg, Germany).

\subsection{Sponge Collection}

Callyspongia sp. (family Callyspongiidae) was collected at a depth of $10 \mathrm{~m}$ in the Red Sea (Ras Mohamed, Sinai, Egypt; (GPS: $27^{\circ} 47.655^{\prime} \mathrm{N} ; 34^{\circ} 12.904^{\prime} \mathrm{W}$ ) in August 2008. The collected sponge was transferred to plastic bags containing seawater and transported to the laboratory. The sponge was identified by R.W.M. van Soest (University of Amsterdam, Amsterdam, The Netherlands).

\subsection{Isolation, Fermentation, and Extract Preparation of Nocardiopsis sp. UR67}

Sponge specimens were rinsed in sterile seawater, cut into pieces of ca. $1 \mathrm{~cm}^{3}$, and then thoroughly homogenized in a sterile mortar with 10 volumes of sterile seawater. The supernatant was diluted in a tenfold series $\left(10^{-1}, 10^{-2}, 10^{-3}\right)$ and subsequently plated out on agar plates. Four different media-M1, ISP medium 2, Oligotrophic medium (OLIGO), and Marine Agar (MA)—were used for the isolation of actinobacteria. All media were supplemented with $0.2 \mu \mathrm{m}$ pore size filtered cycloheximide $(100 \mu \mathrm{g} / \mathrm{mL})$, nystatin $(25 \mu \mathrm{g} / \mathrm{mL})$, and nalidixic acid $(25 \mu \mathrm{g} / \mathrm{mL})$ to facilitate the isolation of 
slow-growing actinobacteria; cycloheximide and nystatininhibit fungal growth, while nalidixic acid inhibits many fast-growing Gram-negative bacteria [44]. All media contained DifcoBacto agar (18 g/L) and were prepared in $1 \mathrm{~L}$ artificial sea water $\left(\mathrm{NaCl} 234.7 \mathrm{~g}, \mathrm{MgCl}_{2} \cdot 6 \mathrm{H}_{2} \mathrm{O} 106.4 \mathrm{~g}, \mathrm{Na}_{2} \mathrm{SO}_{4} 39.2 \mathrm{~g}, \mathrm{CaCl}_{2}\right.$ 11.0 g, $\mathrm{NaHCO}_{3} 1.92 \mathrm{~g}, \mathrm{KCl} 6.64 \mathrm{~g}$, KBr 0.96 g, $\mathrm{H}_{3} \mathrm{BO}_{3} 0.26$ g, $\mathrm{SrCl}_{2} 0.24$ g, NaF 0.03 g, and dd $\mathrm{H}_{2} \mathrm{O}$ to $10.0 \mathrm{~L}$ ). The inoculated plates were incubated at $30^{\circ} \mathrm{C}$ for $6-8$ weeks. Distinct colony morphotypes were picked and restreaked until visually free of contaminants. The isolates were maintained on plates for short-term storage and long-term strain collections. Nocardiopsis sp. UR67 was fermented in 10 Erlenmeyer flasks (2 L), each containing 1 L of ISP 2 (International Streptomyces Project) medium in artificial sea water and incubated at $30{ }^{\circ} \mathrm{C}$ for 10 days with shaking at $150 \mathrm{rpm}$. After fermentation and filtration, the supernatant was extracted with ethyl acetate $(3 \times 500 \mathrm{~mL})$ to give the organic extract for subsequent compound isolation.

\subsection{LC-HR/MS Analysis}

Ethyl acetate extract of $1 \mathrm{mg} / \mathrm{mL}$ in MeOH was analyzed on an Accela HPLC (Thermo Scientific, Karlsruhe, Germany) coupled to a UV detector at 280 and $360 \mathrm{~nm}$ and an Exactive-Orbitrap high resolution mass spectrometer (Thermo Fisher Scientific, Karlsruhe, Germany). The HPLC column was an ACE (ACE, Mainz, Germany) C18, $75 \mathrm{~mm} \times 3.0 \mathrm{~mm}, 5 \mu \mathrm{m}$ column. The mobile phase consisted of purified water (A) and acetonitrile (B) with $0.1 \%$ formic acid in each solvent. The gradient program started with $10 \%$ B linearly increased to $100 \%$ B at a flow rate of $300 \mu \mathrm{L} / \mathrm{min}$ for $30 \mathrm{~min}$ and remained isocratic for 5 min before linearly decreasing back to $10 \% \mathrm{~B}$ in $1 \mathrm{~min}$. The column was then re-equilibrated with $10 \% \mathrm{~B}$ for 9 min before the next injection. The total analysis time for each sample was $45 \mathrm{~min}$. The injection volume was $10 \mu \mathrm{L}$, and the tray temperature was maintained at $12{ }^{\circ} \mathrm{C}$. High resolution mass spectrometry was carried out in both positive and negative ESI ionization modes with a spray voltage at $4.5 \mathrm{kV}$ and capillary temperature at $320^{\circ} \mathrm{C}$. The mass range was set from $m / z$ 150-1500. Both negative and positive ionization switch modes were used to include the highest number of metabolites from the investigated bacterial fractions subjected to LC-HR-ESIMS analysis. The dereplication was achieved for each $m / z$ ion peak with metabolites recorded in the customized databases based on established parameters $(\mathrm{m} / z$ threshold of \pm 3 ppm and retention time) [45], which provided a high level of confidence in metabolites identity; consequently, the number of the remaining unknown metabolites in each bacterial fraction was refined.

\subsection{Metabolites Isolation}

Theethyl acetateextract $(5 \mathrm{~g})$ was fractionated on a silica gel $(250 \mathrm{~g}, 15-25 \mu \mathrm{m}, 120 \mathrm{~cm} \times 2.5 \mathrm{~cm}$, Merck, Darmstadt, Germany) column and eluted with a DCM/MeOH gradient from (90:10\%) to 100\% methanol. The effluents were collected in fractions $(50 \mathrm{~mL}$ each). Similar fractions monitored by TLC were combined and concentrated to yield six raw fractions. Fraction $2(850 \mathrm{mg})$ was further fractionated bySephadex LH-20 column chromatography $(50 \mathrm{~g}, 32-64 \mu \mathrm{m}, 120 \mathrm{~cm} \times 2 \mathrm{~cm}$, Merck, Darmstadt, Germany) eluted with $\mathrm{MeOH}$ to yield five subfractions. Subfractions II and IV (compounds-rich subfractions) were further purified by semi-preparative HPLC using $\mathrm{H}_{2} \mathrm{O} /$ acetonitrile(90:10\%) initially for $10 \mathrm{~min}$, then by a linear gradient to $100 \%$ acetonitrilewithin $60 \mathrm{~min}$, which was then followed by an isocratic elution at $100 \%$ acetonitrilefor a further $10 \mathrm{~min}$ with a flow rate of $2.0 \mathrm{~mL} / \mathrm{min}$ using a C18 column ( $5 \mu \mathrm{m}, 10 \mathrm{~mm} \times 250 \mathrm{~mm}$, Knauer, Berlin, Germany) to yield compound $\mathbf{1}\left(4 \mathrm{mg} ; R_{\mathrm{t}}=14.3 \mathrm{~min}\right)$ and compound $2\left(3 \mathrm{mg} ; R_{\mathrm{t}}=16.5 \mathrm{~min}\right)$ from subfraction II as well as compound $3\left(1 \mathrm{mg} ; R_{\mathrm{t}}=17.1 \mathrm{~min}\right)$ and compound 4 ( $\left.2 \mathrm{mg} ; R_{\mathrm{t}}=17.9 \mathrm{~min}\right)$ from subfraction IV.

\subsection{Marfey's Analysis}

The absolute configurations of the amino acids in compound $\mathbf{1}$ were elucidated by Marfey's derivatization and compared to the corresponding standard amino acids each with $\mathrm{D}$ and $\mathrm{L}$ configurations (Sigma, Darmstadt, Germany) by HPLC. Compound $1(1 \mathrm{mg})$ was initially hydrolyzed with $6 \mathrm{M} \mathrm{HCl}(2 \mathrm{~mL})$ in a water bath at $100^{\circ} \mathrm{C}$ for $24 \mathrm{~h}$. The hydrolysate was cooled to room temperature, 
dried using a vacuum evaporator and dissolved in $100 \mu \mathrm{L}$ of water. The Marfey's derivatization was carried out by adding $100 \mu \mathrm{L}$ of $1 \%$ Marfey's reagent (1-fluoro-2,4-dinitrophenyl-5-L-alanine amid) dissolved in acetone and $20 \mu \mathrm{L}$ of $1 \mathrm{M} \mathrm{NaHCO}_{3}\left(\mathrm{H}_{2} \mathrm{O}\right)$ to $50 \mu \mathrm{L}$ of the hydrolysate of compound 1 as well as $50 \mathrm{mM}$ standard amino acid, respectively, and incubated at $40{ }^{\circ} \mathrm{C}$ for $1 \mathrm{~h}$ with frequent shaking. The reaction was stopped by adding $10 \mu \mathrm{L}$ of $2 \mathrm{M} \mathrm{HCl}$ after cooling. The Marfey's derivatization products were finally dried and prepared in MeOH for further HPLC analysis. The HPLC chromatography was carried out on Gemini-NX RP-C18 column by eluting with $\mathrm{H}_{2} \mathrm{O}$ /acetonitrile (95:5\%) for the first $5 \mathrm{~min}$, linearly gradient to $100 \%$ acetonitrile for $30 \mathrm{~min}$, and staying at $100 \%$ actonitrile for a further $10 \mathrm{~min}$ with a flow rate at $1 \mathrm{~mL} / \mathrm{min}$ and UV detection at $340 \mathrm{~nm}$. The configuration was eventually determined with the observation of the same retention times compared to the standard enantiomeric amino acids [46-48]. Retention times ( $\mathrm{min}$ ) of authentic amino acids were as follows: L-Val (25.4), D-Val (27.3), L-Leu (21.9), D-Leu (22.2), L-Ala (18.7), D-Ala (20.3), L-Trp (27.3), D-Trp (29.6). A better resolution of the L-Ile, D-Ile derivatives was achieved using a linear gradient of acetonitrile in $0.1 \%(v / v)$ aqueous TFA (30-45\% acetonitrile over $50 \mathrm{~min})$ : L-Ile (30.7), D-Ile (38.5).

\subsection{Cytotoxic Activity}

The cytotoxicity of the isolated compounds was evaluated in cell lines using the 3-(4,5-dimethylthiazol-2-yl)-2,5-diphenyltetrazolium bromide (MTT) assay. CT26, HeLa, and MM.1S cells were maintained in RPMI medium (Merck, Darmstadt, Germany), supplemented with 10\% fetal bovine serum (FBS), and grown at $37{ }^{\circ} \mathrm{C}$ and $5 \% \mathrm{CO}_{2}$. HeLa cells $\left(2 \times 10^{4}\right.$ per well) were plated in 96-well tissue culture plates in $100 \mu \mathrm{L}$ cell culture medium. The following day, cells were stimulated overnight in triplicates with the reagents of interest. Cell viability was assessed by crystal violet staining. In case of the CT26 and MM.1S cell lines, cells were seeded in 96 -well plates $\left(7 \times 10^{4}\right.$ cells per well) and were challenged the same day overnight with the reagents of interest; the cytotoxic effect was evaluated using the MTT assay [49]. To normalize cell viability values, each plate included a triplicate of cells treated with the compound carrier DMSO to define $100 \%$ viable cells as well as a triplicate of cells incubated with a cytotoxic mixture (200 ng/ML Tumor Necrosis Factor TNF, $200 \mathrm{ng} / \mathrm{mL}$ CD95L (Fas ligand), $200 \mathrm{ng} / \mathrm{mL}$ TRAIL (TNF-related apoptosis-inducing ligand), $25 \mu \mathrm{g} / \mathrm{mL}$ CHX (Cycloheximide), $1 \%(w / v)$ sodium azide) to define maximal cell death and thus $0 \%$ viability. All other viability values were normalized according to the averages of these triplicates and analyzed by the Graph Pad Prism 5 software (La Jolla, CA, USA).

\subsection{Compounds Characterization}

\subsection{1. (Nocardiotide A) (1)}

Pale yellow solid $\left(4 \mathrm{mg} ; R_{\mathrm{t}}=14.3 \mathrm{~min}\right) \mathrm{UV}(\mathrm{EtOH}) \lambda \max 232,305 \mathrm{~nm}$; its ${ }^{1} \mathrm{H}$ NMR $(\mathrm{CD} 3 \mathrm{OD}$, $600 \mathrm{MHz})$ and ${ }^{13} \mathrm{C}$ NMR (CD3OD, $150 \mathrm{MHz}$ ) data aredetailed anddisplayed in Table 2.

\subsection{2. (Tryptophan) (2)}

Pale yellow crystalline solid $\left(3 \mathrm{mg} ; R_{\mathrm{t}}=16.5 \mathrm{~min}\right)\left(\mathrm{m} . \mathrm{p} .283-285^{\circ} \mathrm{C}\right) ;{ }^{1} \mathrm{H}$ NMR $(\mathrm{CD} 3 \mathrm{OD}, 600 \mathrm{MHz})$ : $\delta 7.20(1 \mathrm{H}, \mathrm{s}, \mathrm{H}-2), 7.61(1 \mathrm{H}, \mathrm{dt}, J=8.0,1.0 \mathrm{~Hz}, \mathrm{H}-4), 7.06(1 \mathrm{H}, \mathrm{td}, J=7.6,1.0 \mathrm{~Hz}, \mathrm{H}-5), 7.14(1 \mathrm{H}, \mathrm{td}, J=7.6$, $1.0 \mathrm{~Hz}, \mathrm{H}-6), 7.38(1 \mathrm{H}, \mathrm{dt}, J=8.0,0.96 \mathrm{~Hz}, \mathrm{H}-7), 3.50(1 \mathrm{H}, \mathrm{dd}, J=4.47,15.3 \mathrm{~Hz}, \mathrm{H}-10 \mathrm{a}), 3.33$ (obscured by solvent, $\mathrm{H}-10 \mathrm{~b}), 4.23(1 \mathrm{H}, \mathrm{dd}, J=4.8,8.1 \mathrm{~Hz}, \mathrm{H} 11) ;{ }^{13} \mathrm{C} \mathrm{NMR}(\mathrm{CD} 3 \mathrm{OD}, 150 \mathrm{MHz}): \delta 125.4(\mathrm{CH}, \mathrm{C}-2)$, 108.0 (C, C-3), 117.0 (CH, C-4), 120.3 (CH, C-5), 123.0 (CH, C-6), 112.6 (CH, C-7), 138.4 (C, C-8), 128.4 (C, C-9), $27.7(\mathrm{CH} 2, \mathrm{C}-10), 54.7(\mathrm{CH}, \mathrm{C}-11), 171.9(\mathrm{C}, \mathrm{C}-12)$. The physical and spectral data were in accordance with those reported in the literature [42]. 


\subsection{3. (Kynurenicacid) (3)}

White amorphous powder; $\left(1 \mathrm{mg} ; R_{\mathrm{t}}=17.1 \mathrm{~min}\right){ }^{1} \mathrm{H}$ NMR (CD3OD, $\left.600 \mathrm{MHz}\right): \delta 7.01(1 \mathrm{H}, \mathrm{s}, \mathrm{H}-3)$, $8.26(1 \mathrm{H}, \mathrm{ddd}, J=8.5,1.4,0.6 \mathrm{~Hz}, \mathrm{H}-5), 7.47(1 \mathrm{H}, \mathrm{td}, J=7.7,1.4 \mathrm{~Hz}, \mathrm{H}-6), 7.78(1 \mathrm{H}, \mathrm{td}, J=7.7,1.0 \mathrm{~Hz}$, $\mathrm{H}-7), 7.88(1 \mathrm{H}, \mathrm{ddd}, J=8.5,1.0,0.6 \mathrm{~Hz}, \mathrm{H}-8) ;{ }^{13} \mathrm{C}$ NMR (CD3OD, $\left.150 \mathrm{MHz}\right): \delta 143.3(\mathrm{C}, \mathrm{C}-2), 110.3(\mathrm{CH}$, C-3), 181.1 (C, C-4), 126.0 (CH, C-5), 126.0 (CH, C-6), 134.3 (CH, C-7), 120.4 (CH, C-8), 141.3 (C, C-9), 126.5 (C, C-10), 164.8 (C, C-11). The physical and spectral data were in accordance with those reported in the literature [43]. This is the first isolation of this compound from microbial origins.

\subsection{4. (4-Amino3-methoxy benzoic acid) (4)}

Pale yellow crystalline powder $\left(2 \mathrm{mg} ; R_{\mathrm{t}}=17.9 \mathrm{~min}\right)\left(\mathrm{m} . \mathrm{p} .185-187{ }^{\circ} \mathrm{C}\right) ;{ }^{1} \mathrm{H}$ NMR $(\mathrm{CD} 3 \mathrm{OD}$, $600 \mathrm{MHz}): \delta 7.61(1 \mathrm{H}, \mathrm{d}, J=1.2 \mathrm{~Hz}, \mathrm{H}-2), 6.79(1 \mathrm{H}, \mathrm{d}, J=9.8 \mathrm{~Hz}, \mathrm{H}-5), 7.53(1 \mathrm{H}, \mathrm{dd}, J=9.8,1.2 \mathrm{~Hz}$, $\mathrm{H}-6) ;{ }^{13} \mathrm{C}$ NMR (CD3OD, $\left.150 \mathrm{MHz}\right): \delta 127.4$ (C, C-1), 112.5 (CH, C-2), 146.8 (C, C-3), 149.3 (C, C-4), $113.9(\mathrm{CH}, \mathrm{C}-5), 123.1(\mathrm{CH}, \mathrm{C}-6)$. The physical and spectral data were in accordance with those reported in the literature.

\section{Conclusions}

In continuation of our interest to isolate and identify new antiproliferative agents from natural sources, the chemical characterization of Nocardiopsis sp.UR67-an actinomycete associated with the sponge (Callyspongia sp.) previously collected from the Red Sea-was conducted alongside with evaluation of the cytotoxic properties of the attained compounds versus the murine CT26 colon carcinoma, the human HeLa cervix carcinoma, and the human MM.1S multiple myeloma cell lines. Ten known metabolites were identified by dereplication using LC-HR-ESI-MS techniques. Additionally, four compounds were isolated and characterized for the first time from the broth culture of Nocardiopsis sp. UR67. Most importantly, one new cyclic hexapeptide-nocardiotide A-was identified, along with tryptophan, kynurenic acid, and 4-amino-3-methoxy benzoic acid. Among them, only nocardiotide A demonstrated significant cytotoxic property.

Supplementary Materials: The following are available online at http:/ / www.mdpi.com/1660-3397/16/9/290/s1, Figures S1-S11: ${ }^{1} \mathrm{H}-\mathrm{NMR},{ }^{13} \mathrm{C}-\mathrm{NMR}, \mathrm{COSY}, \mathrm{HSQC}$, NOESY and HMBC spectra of 1, Figures S12-S17: ${ }^{1} \mathrm{H}-\mathrm{NMR}$, ${ }^{13} \mathrm{C}-\mathrm{NMR}$, COSY, HSQC and HMBC spectra of 2, Figures S18-S21: ${ }^{1} \mathrm{H}-\mathrm{NMR},{ }^{13} \mathrm{C}-\mathrm{NMR}$, COSY and HMBC spectra of 3, Figures S22-S26: ${ }^{1} \mathrm{H}-\mathrm{NMR},{ }^{13} \mathrm{C}-\mathrm{NMR}, \mathrm{COSY}, \mathrm{HSQC}$ and HMBC spectra of 4.

Author Contributions: Conceptualization, U.R.A.; Formal analysis, A.H.I., M.A.F. and U.R.A.; Investigation, E.Z.A., S.Y.D., M.A.A., D.H.; Supervision, M.S.K., M.A.F., S.Y.D. and U.R.A.; Writing一original draft, A.H.I., D.H., E.Z.A. and M.A.A.; Writing一review \& editing, T.A.M.G., H.W. and U.R.A.

Funding: Research in the group of T.A.M.G. is generously funded by the DFG (GU 1233/1-1 and Center for Integrated Protein Science CIPSM). This work was supported by the German Research Foundation (DFG) and the Technical University of Munich (TUM) in the framework of the Open Access Publishing Program.

Acknowledgments: We thank Arwa A. Makki for the fruitful discussion.

Conflicts of Interest: The authors declare no conflict of interest.

\section{References}

1. Yoshida, A.; Seo, Y.; Suzuki, S.; Nishino, T.; Kobayashi, T.; Hamada-Sato, N.; Kogure, K.; Imada, C. Actinomycetal community structures in seawater and freshwater examined by DGGE analysis of $16 \mathrm{~S}$ rRNA gene fragments. Mar. Biotechnol. 2008, 10, 554-563. [CrossRef] [PubMed]

2. Barka, E.A.; Vatsa, P.; Sanchez, L.; Gaveau-Vaillant, N.; Jacquard, C.; Klenk, H.-P.; Clément, C.; Ouhdouch, Y.; van Wezel, G.P. Taxonomy, physiology, and natural products of Actinobacteria. Microbiol. Mol. Biol. Rev. 2016, 80, 1-43. [CrossRef] [PubMed]

3. Abdelmohsen, U.R.; Balasubramanian, S.; Oelschlaeger, T.A.; Grkovic, T.; Pham, N.B.; Quinn, R.J.; Hentschel, U. Potential of marine natural products against drug-resistant fungal, viral, and parasitic infections. Lancet Infect. Dis. 2017, 17, e30-e41. [CrossRef] 
4. Manivasagan, P.; Kang, K.-H.; Sivakumar, K.; Li-Chan, E.C.; Oh, H.-M.; Kim, S.-K. Marine actinobacteria: An important source of bioactive natural products. Environ. Toxicol. Pharmacol. 2014, 38, 172-188. [CrossRef] [PubMed]

5. Manivasagan, P.; Venkatesan, J.; Sivakumar, K.; Kim, S.-K. Pharmaceutically active secondary metabolites of marine actinobacteria. Microbiol. Res. 2014, 169, 262-278. [CrossRef] [PubMed]

6. Li, J.W.-H.; Vederas, J.C. Drug discovery and natural products: End of an era or an endless frontier? Science 2009, 325, 161-165. [CrossRef] [PubMed]

7. Meyer, J. Nocardiopsis, a new genus of the order Actinomycetales. Int. J. Syst. Evol. Microbiol. 1976, 26, 487-493. [CrossRef]

8. Rainey, F.A.; Ward-Rainey, N.; Kroppenstedt, R.M.; Stackebrandt, E. The genus Nocardiopsis represents a phylogenetically coherent taxon and a distinct actinomycete lineage: Proposal of Nocardiopsaceae fam. nov. Int. J. Syst. Evol. Microbiol. 1996, 46, 1088-1092. [CrossRef] [PubMed]

9. Bennur, T.; Ravi Kumar, A.; Zinjarde, S.; Javdekar, V. Nocardiopsis species: A potential source of bioactive compounds. J. Appl. Microbiol. 2015, 120,1-16. [CrossRef] [PubMed]

10. Ibrahim, A.H.; Desoukey, S.Y.; Fouad, M.A.; Kamel, M.S.; Gulder, T.A.; Abdelmohsen, U.R. Natural Product Potential of the Genus Nocardiopsis. Mar. Drugs 2018, 16, 147. [CrossRef] [PubMed]

11. Engelhardt, K.; Degnes, K.F.; Kemmler, M.; Bredholt, H.; Fjærvik, E.; Klinkenberg, G.; Sletta, H.; Ellingsen, T.E.; Zotchev, S.B. Production of a new thiopeptide antibiotic, TP-1161, by a marine Nocardiopsis species. Appl. Environ. Microbiol. 2010, 76, 4969-4976. [CrossRef] [PubMed]

12. Shin, J.; Seo, Y.; Lee, H.-S.; Rho, J.-R.; Mo, S.J. A new cyclic peptide from a marine-derived bacterium of the genus Nocardiopsis. J. Nat. Prod. 2003, 66, 883-884. [CrossRef] [PubMed]

13. Raju, R.; Piggott, A.M.; Quezada, M.; Capon, R.J. Nocardiopsins C and D and nocardiopyroneA: Newpolyketides from an Australian marine-derived Nocardiopsis sp. Tetrahedron 2013, 69, 692-698. [CrossRef]

14. Dashti, Y.; Grkovic, T.; Abdelmohsen, U.R.; Hentschel, U.; Quinn, R.J. Actinomycete Metabolome Induction/Suppression with N-Acetylglucosamine. J. Nat. Prod. 2017, 80, 828-836. [CrossRef] [PubMed]

15. Raju, R.; Piggott, A.M.; Conte, M.; Tnimov, Z.; Alexandrov, K.; Capon, R.J. Nocardiopsins: New FKBP12-Binding Macrolide Polyketides from an Australian Marine-Derived Actinomycete, Nocardiopsis sp. Chem. Eur. J. 2010, 16, 3194-3200. [CrossRef] [PubMed]

16. Tian, S.; Yang, Y.; Liu, K.; Xiong, Z.; Xu, L.; Zhao, L. Antimicrobial metabolites from a novel halophilic actinomycete Nocardiopsis terrae YIM 90022. Nat. Prod. Res. 2014, 28, 344-346. [CrossRef] [PubMed]

17. Raju, R.; Piggott, A.M.; Huang, X.-C.; Capon, R.J. Nocardioazines: A novel bridged diketopiperazine scaffold from a marine-derived bacterium inhibits P-glycoprotein. Org. Lett. 2011, 13, 2770-2773. [CrossRef] [PubMed]

18. Fu, P.; Liu, P.; Qu, H.; Wang, Y.; Chen, D.; Wang, H.; Li, J.; Zhu, W. $\alpha$-Pyrones and diketopiperazine derivatives from the marine-derived actinomycete Nocardiopsis dassonvillei HR10-5. J. Nat. Prod. 2011, 74, 2219-2223. [CrossRef] [PubMed]

19. Kim, Y.; Ogura, H.; Akasaka, K.; Oikawa, T.; Matsuura, N.; Imada, C.; Yasuda, H.; Igarashi, Y. Nocapyrones: $\alpha$-and $\gamma$-Pyrones from a Marine-Derived Nocardiopsis sp. Mar. Drugs 2014, 12, 4110-4125. [CrossRef] [PubMed]

20. Kim, M.C.; Kwon, O.-W.; Park, J.-S.; Kim, S.Y.; Kwon, H.C. Nocapyrones, H-J, 3, 6-disubstituted $\alpha$-pyrones from the marine actinomycete Nocardiopsis sp. KMF-001. Chem. Pharm. Bull. 2013, 61, 511-515. [CrossRef] [PubMed]

21. Ding, Z.-G.; Zhao, J.-Y.; Li, M.-G.; Huang, R.; Li, Q.-M.; Cui, X.-L.; Zhu, H.-J.; Wen, M.-L. Griseusins F and G spiro-naphthoquinones from a tin mine tailings-derived alkalophilic Nocardiopsis species. J. Nat. Prod. 2012, 75, 1994-1998. [PubMed]

22. Gao, X.; Lu, Y.; Xing, Y.; Ma, Y.; Lu, J.; Bao, W.; Wang, Y.; Xi, T. A novel anticancer and antifungusphenazine derivative from a marine actinomycete BM-17. Microbiol. Res. 2012, 167, 616-622. [CrossRef] [PubMed]

23. Lu, C.; Li, Y.; Wang, H.; Wang, B.; Shen, Y. A new phenoxazine derivative isolated from marine sediment actinomycetes, Nocardiopsis sp. 236. Drug Discov. Ther. 2013, 7, 101-104. [PubMed]

24. He, J.; Roemer, E.; Lange, C.; Huang, X.; Maier, A.; Kelter, G.; Jiang, Y.; Xu, L.-H.; Menzel, K.-D.; Grabley, S.; et al. Structure, derivatization, and antitumor activity of new griseusins from Nocardiopsis sp. J. Med. Chem. 2007, 50, 5168-5175. [CrossRef] [PubMed] 
25. Tian, S.-Z.; Pu, X.; Luo, G.; Zhao, L.-X.; Xu, L.-H.; Li, W.-J.; Luo, Y. Isolation and characterization of new $p$-terphenyls with antifungal, antibacterial, and antioxidant activities from halophilic actinomycete Nocardiopsis gilva YIM 90087. J. Agric. Food Chem. 2013, 61, 3006-3012. [CrossRef] [PubMed]

26. Kase, H.; Iwahashi, K.; Matsuda, Y. K-252a, a potent inhibitor of protein kinase C from microbial origin. J. Antibiot. 1986, 39, 1059-1065. [CrossRef] [PubMed]

27. Grkovic, T.; Abdelmohsen, U.R.; Othman, E.M.; Stopper, H.; Edrada-Ebel, R.; Hentschel, U.; Quinn, R.J. Two new antioxidant actinosporin analogues from the calcium alginate beads culture of sponge-associated Actinokineospora sp. strain EG49. Bioorg. Med. Chem. Lett. 2014, 24, 5089-5092. [CrossRef] [PubMed]

28. Cho, J.Y.; Williams, P.G.; Kwon, H.C.; Jensen, P.R.; Fenical, W. Lucentamycins A-D, cytotoxic peptides from the marine-derived actinomycete Nocardiopsis lucentensis. J. Nat. Prod. 2007, 70, 1321-1328. [CrossRef] [PubMed]

29. Zhou, J.; Sun, C.; Wang, N.; Gao, R.; Bai, S.; Zheng, H.; You, X.; Li, R. Preliminary report on the biological effects of space flight on the producing strain of a new immunosuppressant, Kanglemycin C. J. Ind. Microbiol. Biotechnol. 2006, 33, 707-712. [CrossRef] [PubMed]

30. Poumale, H.M.; Ngadjui, B.T.; Helmke, E.; Laatscha, H. New anthraquinones from a marine Streptomyces sp.-isolation, structure determination and biological activities. Z. Naturforsch. B 2006, 61, 1450-1454. [CrossRef]

31. Zhou, X.; Fenical, W. The unique chemistry and biology of the piericidins. J. Antibiot. (Tokyo) 2016, 69, 582-593. [CrossRef] [PubMed]

32. Fujioka, K.; Furihata, K.; Shimazu, A.; Hayakawa, Y.; Seto, H. Isolation and characterization of atramycin A and atramycin B, new isotetracenone type antitumor antibiotics. J. Antibiot. (Tokyo) 1991, 44, 1025-1028. [CrossRef]

33. Urakawa, A.; Sasaki, T.; Yoshida, K.; Otani, T.; Lei, Y.; Yun, W. IT-143-A and B, novel piericidin-group antibiotics produced by Streptomyces sp. J. Antibiot. (Tokyo) 1996, 49, 1052-1055. [CrossRef] [PubMed]

34. Harada, S. Studies on lankacidin-group (T-2636) antibiotics. VI. Chemical structures of lankacidin-group antibiotics. II. Chem. Pharm. Bull. (Tokyo) 1975, 23, 2201-2210. [CrossRef] [PubMed]

35. Patton, S.M.; Cropp, T.A.; Reynolds, K.A. A novel delta(3),delta(2)-enoyl-CoA isomerase involved in the biosynthesis of the cyclohexanecarboxylic acid-derived moiety of the Polyketideans atrienin A. Biochemistry 2000, 39, 7595-7604. [CrossRef] [PubMed]

36. Cheng, K.C.; Cao, S.; Raveh, A.; MacArthur, R.; Dranchak, P.; Chlipala, G.; Okoneski, M.T.; Guha, R.; Eastman, R.T.; Yuan, J.; et al. Actinoramide A Identified as a Potent Antimalarial from Titration-Based Screening of Marine Natural Product Extracts. J. Nat. Prod. 2015, 78, 2411-2422. [CrossRef] [PubMed]

37. Du, Y.; Wang, Y.; Huang, T.; Tao, M.; Deng, Z.; Lin, S. Identification and characterization of the biosynthetic gene cluster of polyoxypeptin A, a potent apoptosis inducer. BMC Microbiol. 2014, 14, 30. [CrossRef] [PubMed]

38. Wiese, J.; Abdelmohsen, U.R.; Motiei, A.; Humeida, U.H.; Imhoff, J.F. Bacicyclin, a new antibacterial cyclic hexapeptide from Bacillus sp. strain BC028 isolated from Mytilusedulis. Bioorg. Med. Chem. Lett. 2018, 28, 558-561. [CrossRef] [PubMed]

39. Ibrahim, S.R.; Edrada-Ebel, R.; Mohamed, G.A.; Youssef, D.T.; Wray, V.; Proksch, P. Callyaerin G, a new cytotoxic cyclic peptide from the marine sponge Callyspongia aerizusa. Arkivoc 2008, 2008, 164.

40. Wu, Z.-C.; Li, S.; Nam, S.-J.; Liu, Z.; Zhang, C. Nocardiamides A and B, two cyclohexapeptides from the marine-derived actinomycete Nocardiopsis sp. CNX037. J. Nat. Prod. 2013, 76, 694-701. [CrossRef] [PubMed]

41. Hsieh, P.-W.; Chang, F.-R.; Wu, C.-C.; Wu, K.-Y.; Li, C.-M.; Chen, S.-L.; Wu, Y.-C. New cytotoxic cyclic peptides and dianthramide from Dianthus superbus. J. Nat. Prod. 2004, 67, 1522-1527. [CrossRef] [PubMed]

42. Al-Khalil, S.; Alkofahi, A.; El-Eisawi, D.; Al-Shibib, A. Transitorine, a new quinoline alkaloid from Ephedra transitoria. J. Nat. Prod. 1998, 61, 262-263, Correction in 1999, 62, 1214. [CrossRef] [PubMed]

43. Elsayed, Y.; Refaat, J.; Abdelmohsen, U.R.; Ahmed, S.; Fouad, M.A. Rhodozepinone, a new antitrypanosomal azepino-diindole alkaloid from the marine sponge-derived bacterium Rhodococcus sp. UA13. Med. Chem. Res. 2017, 26, 2751-2760. [CrossRef]

44. Webster, N.S.; Wilson, K.J.; Blackall, L.L.; Hill, R.T. Phylogenetic diversity of bacteria associated with the marine sponge Rhopaloeidesod orabile. Appl. Environ. Microbiol. 2001, 67, 434-444. [CrossRef] [PubMed] 
45. Tawfike, A.F.; Tate, R.; Abbott, G.; Young, L.; Viegelmann, C.; Schumacher, M.; Diederich, M.; Edrada-Ebel, R. Metabolomic Tools to Assess the Chemistry and Bioactivity of Endophytic Aspergillus Strain. Chem. Biodivers. 2017, 14, e1700040. [CrossRef] [PubMed]

46. Bhushan, R.; Brückner, H. Marfey's reagent for chiral amino acid analysis: A review. Amino Acids 2004, 27, 231-247. [CrossRef] [PubMed]

47. Kochhar, S.; Christen, P. Amino acid analysis by high-performance liquid chromatography after derivatization with 1-fluoro-2, 4-dinitrophenyl-5-L-alanine amide. Anal. Biochem. 1989, 178, 17-21. [CrossRef]

48. Marfey, P. Determination of D-amino acids. II. Use of a bifunctional reagent, 1,5-difluoro-2,4-dinitrobenzene. Carlsberg Res. Commun. 1984, 49, 591. [CrossRef]

49. Cheng, C.; Othman, E.M.; Stopper, H.; Edrada-Ebel, R.; Hentschel, U.; Abdelmohsen, U.R. Isolation of Petrocidin A, a New Cytotoxic Cyclic Dipeptide from the Marine Sponge-Derived Bacterium Streptomyces sp. SBT348. Mar. Drugs 2017, 15, 383. [CrossRef] [PubMed]

(C) 2018 by the authors. Licensee MDPI, Basel, Switzerland. This article is an open access article distributed under the terms and conditions of the Creative Commons Attribution (CC BY) license (http://creativecommons.org/licenses/by/4.0/). 